\title{
The Concept of Sovereign Personality as a Topical, Historical-Philosophical and Humanitarian Problem
}

\author{
Viazinkin A.Yu. \\ Department «History and Philosophy» \\ Tambov State Technical University \\ Tambov, Russia \\ vyazinkin@yandex.ru
}

\begin{abstract}
The subject of this research is the problem of evolution of the concept of sovereign individual from the Age of Enlightenment to modernity. Historical-philosophical analysis identified the main trends of this concept development, revealed ideological connections with such areas of thought as utilitarianism, nihilism, anarchism, philosophical anthropology, Nietzscheanism, libertarianism. The main socio-philosophical and philosophical-anthropological definitions related to the concept of "sovereign individual" are defined, as well as the main strategies of the individual in the "struggle for individuality." The concept of sovereign individual is related to the principle of the complex (economic, social, political, moral) liberation of personality, it sums up the achievements of the European philosophy of freedom of the 19th-20th centuries. In the light of modern humanitarian problems, there is a danger of understanding "sovereign individual" as a nihilistic figure, freed from history and tradition, as a person of aesthetic game, located "on the other side of good and evil." At the same time, modern transhumanistic concepts of post-human imply a change in the nature of personality, that is, a fundamental metamorphosis of the basic configuration of human. The dominant trends of globalization, recognized as both negative and positive, can pose a threat to individual autonomy, as it was understood in Western European philosophy and is understood nowadays.
\end{abstract}

Keywords-history of philosophy; social philosophy; sovereign inividual; nihilism; modern humanitarian challenges.

\section{INTRODUCTION}

Modern humanitarian problems demand many-sided, thorough interdisciplinary study. This complex of problems includes a lot of themes, which demand thorough study. One of such kind of topics is the question of personality prospects in the world of globalization and the urgency of sovereign personality conceptions as historical-philosophic theory and humanitarian problem. This topic content is extremely important for principle social, psychological and philosophic problems solution, connected with the conditions of personality independence preservation. The problem of sovereign personality is urgent not only in terms of humanistic tradition of philosophy and humanitarian sciences support, but also in context of civilization concerns, connected with the process of globalization intensification and the popularity of the idea of post-person in modern concept of transhumanism. The aim of the research work is to study the content of sovereign personality problem as historical-philosophic and humanitarian problem. In modern world the problem of progressive social and economic society development in terms of sovereign rights of personality preservation is very important.

\section{LITERATURE REVIEW}

"Sovereign personality" concept in modern research literature is very often connected with F. Nietzsche and his philosophy of freedom [1]. Undoubtedly, German philosopher vividly presented his version of "sovereign personality" and influenced greatly the theorists of sovereign personality of the XX century. P. Poellner writes about the characteristic of anthropological ideal (this ideal corresponds with the type of sovereign personality offered by F. Nietzsche): "the constitutive conditions of full-fledged, autonomous rather than heteronomous selfhood" [2, p. 152].

One of the most urgent philosophic explanations of "sovereignty" notion in social-philosophic aspect belongs to Italian philosopher G. Agamben. Critical consideration of his philosophic ideas helps to decode implicit notions of humanitarian direction thinkers concerning theoretical and practical prospects of a personality in the future [3]

The emphases made by modern European researchers show, that they consider more urgent humanitarian aspect of the question, not historical-philosophic content of sovereign personality problem.

Modern researchers underline that sovereign personality can be understood in the context of apollonistic culturalanthropologic code: "sovereignty is not an entity, but there is constantly conquered distance concerning oneself" [4, p. 65]. Distance concerning oneself is connected with the distance concerning other people in the same way as self-irony is connected with irony. If irony is a strategy of a nihilist (who is deceiving himself with only seeming sovereignty), then selfirony is a real strategy of sovereign personality.

Classical understanding of sovereign personality problem is still urgent in philosophic science. It is a question of "struggle for independence" and existential self-determination: "creating oneself orienting toward reality, realizing it; resist social institutes, which suppress personality" [5, p. 96]. 
The problem of sovereign personality, of course, doesn't have strictly philosophic character. In postindustrial society, where the problems of comfort and psychological well-being became key questions of life, the notions of personality independence and autonomy are put into modern renewed axiological system of coordinates: "Psychological sovereignty is a personality's quality, which is responsible for independence and autonomy achievement, which are necessary for a person's psychological well-being support" [6, p. 100].

In the theory of French philosopher E. Morin the problem of sovereign personality is considered in the context of supporting it ecosystem: "Any organism, in order to preserve independence, should be open for an ecosystem, owing to which it is transformed" [7, p. 61]. In this case it is reasonable to ask the following question: "Is it possible to speak about some independence of a person?". In a biological aspect it is not reasonable as any "sovereignty" of a subject has its source in a form of outer ecosystem. On the other hand, the problem of the definite autonomy achievement is solved depending on the configuration of the set ecosystem. The philosopher wrote about "dependent autonomy" [8, p. 242]. Anyhow, we should speak about personality sovereignty in social and humanitarian senses.

\section{RESEARCH METHODOLOGY}

The work is based on social-philosophic and historicalphilosophic methods. We also used the method of comparative analysis, which provides different theoretical conceptions comparison and general traits and differences between them determination. On the basis of this analysis we came to the conclusions of general-theoretical character, which concern sovereign personality concept study, as an urgent historicalphilosophic and humanitarian problem. The aim of the research achievement provides taking into account the principle of logic and historical approaches unity, in terms of the leading role of the logic approach, as one of the most important principles of social-philosophic and philosophicanthropological analysis.

\section{RESULTS}

"Sovereign personality" is the product of the Age of Enlightenment. Key aspects of the theory of personality liberation were formed during this period. Sovereign personality determines its liberation in three main directions: 1) moral; 2) social-economic; 3) political. The first meant personality liberation from not urgent tradition dogmas, first of all from religious rules, from classical notions of God, morality, family and marriage. Emerging modern had to transform canon from the state of ideological steadiness into pluperfect. The second and the third items provided revolutionary transformations, as a result of which a person gained self and the whole difficult system of rules, which nowadays is extremely steady in civilized society.

It is interesting that among the thinkers of the Age of Enlightenment the image of sovereign personality corresponded with their interpretation of an anthropological ideal. T.B. Dlugach correctly mentioned that " the image of a natural savage", some primitive individual, thinkers of the XVII-XVIII centuries present as some autonomous personality - that sovereign subject, who is the base of democratic social structures"[9, p. 85]. Among modern conceptions of sovereign personality we can define the direction, which solves the problem of sovereignty not in favor of a person. One of the founders of philosophic anthropology A. Gehlen wrote about "insufficiency" of a person, which is in his biological inadaptability to life, in condiitioned by natural environment chronical need. In this state a person is not self-reliant, a person is in a continuous state of "anxiety". "Anxiety" (Sorge), according to German philosopher M. Heidegger, is an important condition for being in the world (In-der-Welt-Sein). Heidegger's Dasein is "anxiety": not a subject, but a being in general. In other words, a person's being in the world is possible only in terms of "anxiety". "Anxiety" is inevitable.

French philosopher Georges Bataille, who saw direct connection between sovereignty and libertinism, said that a human being lost his sovereignty. Real sovereignty has an animal: "an animal can't but know the main law, that his wild impulses are the violation of this law themselves; an animal violates the law consciously and sovereignly" [10, p. 547].

A century earlier Russian philosopher A.I. Gertsen wrote about the fact that a human being lost his "wild accuracy of the instinct" [11, p. 67]. Gertsen connected this "loss" with the transfer of civilization to urban phase of development with its labour specific specialization. Thus, a person, who has a narrowly-specialized profession, loses the ability to provide oneself and realize all his needs independently. A personality loses self-sufficiency, autonomy, sovereignty.

"Nihilistic experience" of the world philosophy made people see the problem of sovereign personality not only from the position of sovereignty principle theoretical substantiation and the corresponding criteria creation for a sovereign subject determination, but also from the point of strategy of a human being liberation. The key strategy of nihilism is irony. Irony destroys fundamental basis of any thesis and leads to meanings elimination. Reality, which earlier had legitimacy on rational grounds, under the influence of irony gains relativistic definitions. Contemporary American philosopher R. Rorty offered the type of "liberal ironiste", at the second part of the $\mathrm{XX}$ century, as an ideal anthropological figure. In terms of postmodernism, when all things and sences undergo aesthetic scrining, an ideal type gains vivid elitist characteristics: "It assumes that the aim of human society is not general happiness provision but the opportunity for especialiy gifted human beings to become autonomous - to achieve their goal" [12, p. 142]. This "aesthetic position" in postindustrial world is strictly literaturecentric. Philosophy is considered only as "genre" of culture [13]. The question about sovereign personality is solved in the concept of Rorty by means of nontrivial artistic-philosophic strategy: "Private autonomy can be gained by redescribing one's past in away which had not occurred to the past" [12, p. 101].

Special place among the theorists of sovereign personality of the XX century takes German thinker and writer E. Jünger. The latest Jünger concept of sovereign personality ("The Glass Bees", 1957, "Eumeswil", 1977) is the continuation of the 
author's aleatory aesthetics ("The Adventurous Heart", 1929). Risk and game in mythology of modern became the substantiation for Jünger's sovereign personality theory. "When the captain leaves his ship, he leave it to God. But a real captain goes to the bottom together with his ship" [14, p. 50]. Sovereign personality according to Jünger is identical with "integral personality" notion, the integrity of which is in entire control of a human being over own position in the world. German thinker considered that the right for freedom comes from inner vital potential of a human being, which has non-material nature. Thus, personality sovereignty gains metaphysical substantiation: "There deep inside there is our kingdom, our monarchy, our best republic" [14, p. 89].

For "sovereign personality" notion conceptualization Jünger created special type of personality, an ideal anthropologic figure of an "Anarchist". In this concept anarchic and nihilistic content was minimized owing to philosopher's distance, owing to the principle of noninvolvement into the existing systems and social institutes. Anarchist "can appear any moment from any system of demands, which are placed by the state, society, church and also from being" $[15$, p. 206]. At the same time, this type of sovereign personality doesn't have Nietzschean overtones, transcendental accentuations. In this meaning immanently peculiar to a human being freedom is understood by Jünger not in Nietzschean, but in Stirner sense: "For him his own scale is enough- writes Jünger about the type of "Anarchist", freedom for him is not the aim; it is his property" [15, p. 376].

During the second part of XX century was the concept of sovereign personality, formulated in artistic-philosophic and general theoretical works of American philosopher A. Rand. Combining egocentrism and utilitarianism on the basis of modernized "sensible egoism" conception, the author of objectivism influenced greatly social-philosophic content of political doctrines: from libertarianism to conservatism.

"Sensible egoism" in understanding of Rand is led to logical limit. She thought that individual happiness of a personality was the final aim of any life: "Moral aim of a human being's life is personal happiness achievement. It doesn't mean that he doesn't care for other people, that a human life, apart from his own, isn't valuable for him and that he wouldn't help people in extreme situation. However, it means that he doesn't have to devote all his life to somebody's well-being provision and sacrifice himself in the sake of other people" [16, p. 61].

The scale of moral values, according to conception of Rand, is conditioned by this or that estimated element of life in achieving happiness by a person. Any altruistic sacrifice is a vain effort, which doesn't provide personal happiness achievement; altruism is a mistake, because "a human being is not a sacrificial animal" [16, p.53].

Libertarian pathos of Rand's philosophy quasi- ethically justifies wild aggression of capitalistic society. Anthropological ideal of Rand is individualist and egoist, who doesn't care for social interests, principles of solidarity, he is morally autonomous. Society should be anarchistic in order to let this ideal type with his nihilistic ethics be realized.
Anarchic- nihilistic utilitarianism overcoming in theoretic aspect of subject sovereignty idea is possible only in case of solidarity principle substantiation. According to this principle personality formation and individuation can't be achieved without social sanction: "only through recognition by society can be realized as a personality, as a person" [17, p. 78].

Futurological theory about the future society by $\mathrm{J}$. Agamben means fundamental change in social connections landscape. The philosopher thinks that in a new society there wouldn't be preconditions and subjects and social relations and connections, personal life would become maximum clear $[18,17]$. However, this position doesn't explain how the problem of personality sovereignty would be solved in the future society.

\section{CONCLUSION}

Sovereign personality conception is an urgent historicalphilosophic and humanitarian problem. The question of ethical control over utilitarian-individualistic tendencies of "sovereign personality" definitions still stay urgent. These definitions tend to gain nihilism world view and moral solipsism. Taking into account the specificity of current global world problems both are not acceptable. At the same time, it should be noted, that declarative statement of "the rights of a human being" presents a weak immune complex against viruses of contemporaneity, which attack a human being's personality. Thus, without "sovereign personality" notion conceptualization, philosophic (philosophic-anthropologic) problem solution is impossible, both in theoretical and practical spheres.

\section{References}

[1] M. Rukgaber, "The "Sovereign Individual" and the "Ascetic Ideal": On a Perennial Misreading of the Second Essay of Nietzsche's On the Genealogy of Morality", Journal of Nietzsche Studies, 2012, 43 (2), pp. 213-239.

[2] P. Poellner, "Nietzschean Freedom," Gemes \& May. 2009, pp. 151-180.

[3] G.E. Primera Villamizar, "Potentiality, sovereignty and bare life: a critical reading of Giorgio Agamben", Ideas y Valores. 2014, vol. 63, 156, pp. 79-99.

[4] E.A. Polyakova, "One more time about "free minds", or how is sovereign individual possible?", Philosophic magazine. 2015, vol. 8, 1, pp. 57-66.

[5] V.M. Rozin, "Self-institutionalization and reality institutionalization as the way of life of new-European personality and philosopher", Questions of philosophy. 2009, 7, pp. 91-107.

[6] S.K. Nartova-Bochaver, "Psychological sovereignty connection and social beliefs: borders of a personality in the context of "a big society", Social psychology and society. 2017, vol. 8, 3, pp. 100-114.

[7] L.P. Kiyashchenko, "Personality as a hologram in transdisciplinary culture", Questions of philosophy. 2017, 11, pp. 58-67.

[8] E. Morin, "Method. Nature of Nature", Moscow. 2005.

[9] T.B. Dlugach, "Heroic action of common sense, or the idea of sovereign personality formation", Moscow. 1995.

[10] G. Bataille, "Erotica", Cursed part: Sacral sociology, Moscow. 2006, pp 491-702.

[11] A.I. Gertsen, "Collection of works in 30 volumes. Volume VI.", Moscow. 1955, 549.

[12] R. Rorty, "Contingency, irony, and solidarity", Cambridge University Press. 1989, 201.

[13] R. Rorty, J.B. Schneewind and Q. Skinner, editors, "Philosophy in History”, Cambridge: Cambridge University Press. 1984.

[14] E. Jünger, "Glass bees", Moscow. 2019.

[15] E. Jünger, "Evmesvil", Moscow. 2013. 
[16] A. Rand, "Virtue of egoism", Moscow. 2011

[17] G. Agamben, "Nudity", Moscow. 2014.

[18] Aleksandr S. Kuznetsov. Russian Professor' meeting. The Russian Journal of Physical Education and Sport. 2019, 14(1), pp. 17-22. DOI: 10.14526/2070-4798-2019-14-1-18-24.

[19] G. Agamben, "The future community", Moscow. 2008. 